\title{
Long-lasting chronic high load carriage of Epstein-Barr virus is more common in young pediatric renal transplant recipients
}

\author{
Susanne Westphal Ladfors ${ }^{1,2} \cdot$ Jenny K. Lindahl ${ }^{3,4}$ (D) $\cdot$ Sverker Hansson ${ }^{1,2} \cdot$ Per Brandström $^{1,2} \cdot$ Rune Andersson ${ }^{3,4}$. \\ Marianne Jertborn ${ }^{3,4}$. Magnus Lindh ${ }^{4,5}$. Susanne Woxenius ${ }^{3,4}$. Vanda Friman ${ }^{3,4}$
}

Received: 6 August 2019 / Revised: 22 September 2019 / Accepted: 14 October 2019 / Published online: 4 December 2019

(C) The Author(s) 2019

\begin{abstract}
Background Epstein-Barr virus (EBV) infections can induce post-transplant lymphoproliferative disorder (PTLD). A chronic high load (CHL), as indicated by long-term high EBV DNA levels after transplantation, has been associated with an enhanced risk of PTLD. We aimed to evaluate incidence, time of occurrence, risk factors, and outcome of EBV CHL carrier state after pediatric renal transplantation.

Methods A retrospective study of 58 children aged 1-17 years (median 10), who underwent renal transplantation between January 2004 and June 2017 at a single medical center. EBV IgG antibodies in serum were analyzed before and yearly after transplantation. EBV DNA in whole blood were analyzed weekly for the first 3 months post-transplant, monthly up to 1 year and then at least once yearly. CHL was defined as EBV DNA $\geq 4.2 \log _{10} \mathrm{Geq} / \mathrm{ml}$ in $>50 \%$ of the samples during $\geq 6$ months.

Results At transplantation, $31(53 \%)$ patients lacked EBV IgG and $25(81 \%)$ of them developed primary EBV infection posttransplant. Of the 27 seropositive patients, 20 (74\%) experienced reactivation of EBV. Altogether, 14 (24\%) children developed CHL, starting at a median of 69 days post-transplant and lasting for a median time of 2.3 years (range 0.5-6.5), despite reduction of immunosuppression. Patients with CHL were younger and 11/14 were EBV seronegative at transplantation. No child developed PTLD during median clinical follow-up of 7.8 years (range $0.7-13$ ).

Conclusions CHL was frequent, long lasting, and occurred mainly in young transplant recipients. The absence of PTLD suggests that monitoring of EBV DNA to guide immunosuppression was effective.
\end{abstract}

Keywords Epstein-Barr virus. EBV DNA $\cdot$ Chronic high load carrier $\cdot$ Infection. Pediatric $\cdot$ Renal transplantation

Susanne Westphal Ladfors and Jenny K. Lindahl contributed equally to this work.

Jenny K. Lindahl

jenny.lindahl@vgregion.se

1 Department of Pediatrics, Queen Silvia Children's Hospital, Sahlgrenska University Hospital, Region Västra Götaland, Gothenburg, Sweden

2 Department of Pediatrics, Institute of Clinical Sciences, Sahlgrenska Academy, University of Gothenburg, Gothenburg, Sweden

3 Department of Infectious Diseases, Sahlgrenska University Hospital, Region Västra Götaland, SE-416 85 Gothenburg, Sweden

4 Department of Infectious Diseases, Institute of Biomedicine, Sahlgrenska Academy, University of Gothenburg,

Gothenburg, Sweden

5 Department of Clinical Microbiology, Sahlgrenska University Hospital, Region Västra Götaland, Gothenburg, Sweden

\section{Abbreviations}

CAKUT Congenital anomalies of the kidney and urinary tract

CHL Chronic high viral load

CMV Cytomegalovirus

$\mathrm{CV} \quad$ Coefficient of variation

D/R Donor/recipient

EBV Epstein-Barr virus

ELISA Enzyme-linked immunosorbent assay for detection of antibodies

Geq Genome equivalents

GFR Glomerular filtration rate

HLA Human leucocyte antigen

LVL Low viral load

MMF Mycophenolate mofetil

PCR Polymerase chain reaction

PTLD Post-transplant lymphoproliferative disorder

SOT Solid organ transplantation 
Tx Transplantation, transplant

UVL Undetectable viral load

\section{Introduction}

Epstein-Barr virus (EBV) infection may constitute a serious risk for EBV-associated complications in transplant recipients, whose cellular and humoral response is compromised by immunosuppressive therapy $[1,2]$. Post-transplant lymphoproliferative disorder (PTLD) develops due to uncontrolled proliferation of lymphocytes after solid organ (SOT) or hematopoietic stem cell transplantation [3, 4]. The vast majority of PTLD cases are EBV-related [5-8]. Previous studies have indicated that the incidence of PTLD is higher in children than in adults [9]. The risk for PTLD in the pediatric SOT population is highest after intestinal transplantation (26.8\%), followed by heart-lung (19.5\%), heart (7.7-12.9\%), liver (4\%), and kidney transplantation (1-7\%) [10-18]. EBV-associated PTLD in pediatric renal transplant recipients has been associated with graft loss [19] and has a mortality rate of $32-48 \%$ [15, 20, 21].

According to many studies, important risk factors for PTLD in pediatric graft recipients are the lack of EBV IgG antibodies at the time of transplantation, the overall burden of immunosuppressive therapy, the presence of a concomitant primary cytomegalovirus (CMV) infection and high EBV DNA levels in blood [7, 14, 16, 22-24]. However, in other studies, transplant recipients have been observed to display high EBV loads without developing PTLD [25, 26]. There is also conflicting data on whether a long-lasting period of high EBV load is a predictor for the later development of EBVrelated PTLD. The incidence of chronic high EBV load carrier state, as defined by Green et al. [17], was $8 \%$ in a study of pediatric renal transplant recipients [27]. Despite the association between EBV infection and the risk of developing PTLD after pediatric renal transplantation, there is still no consensus on viral load monitoring or the benefits of EBV-specific antiviral treatment in this population.

The aim of our study was to evaluate the incidence, time of occurrence, risk factors, and outcome of EBV chronic high load (CHL) carrier state after pediatric renal transplantation.

\section{Methods}

\section{Patients and data collection}

We performed a retrospective, single-center study of children undergoing renal transplantation at the Queen Silvia Children's Hospital, Sahlgrenska University Hospital, in Gothenburg, Sweden. Our renal transplantation program began in 1986 and since then more than 100 children have been transplanted. From 2004 and on, patients have been monitored post- transplant with quantitative PCR for EBV and CMV. All 58 children below 18 years of age who had their first renal transplant between January 2004 and June 2017 were included and followed regularly until February 2018 . The patients were censored when reaching 18 years of age $(n=31)$, at the time of retransplantation $(n=1)$, or at the time of death $(n=1)$.

All patients were tested for human leucocyte antigens (HLA-A, B, C, DR, and DQ). Transplant recipients were cross-matched against donors using complement-dependent cytotoxicity (CDC) assay and flow cytometric lymphocyte crossmatch. A positive CDC was a contraindication for transplantation.

Serological analyses of donors and recipients regarding EBV and CMV antibodies (EBV in donors since 2006) were performed, along with post-transplant serial measurements of EBV and CMV DNA levels. Patients were seen three times weekly during the first month, twice a week for the following 2 months, once a week up to 6 months, and once every other week until 1 year post-transplant. Thereafter, clinical visits were gradually tapered to every sixth to eighth week. The patients had follow-up appointments at our hospital at least once a year. Data were collected at these visits as well as from medical charts kept at local hospitals. Routine clinical status and laboratory tests, including serum creatinine and tacrolimus trough concentration in blood, were assessed at each clinical visit. Glomerular filtration rate (GFR) measured by chromium-51-ethylene diamine tetraacetic acid clearance was performed at 3 months, 1 year, and yearly posttransplant thereafter.

Using a clinical chart review, we systematically extracted data that included diagnosis, age at transplantation, gender, donor source, HLA mismatches, immunosuppressive regimen, antiviral medication, EBV and CMV serology, and DNA levels, as well as clinical symptoms of infections, GFR, and survival data.

\section{Immunosuppressive protocol}

The initial immunosuppressive treatment is summarized in Table 1. The standard protocol included corticosteroids, calcineurin inhibitors (CNI; tacrolimus/cyclosporine A), and mycophenolate mofetil (MMF). All patients received induction therapy with methylprednisolone, which since 2010 was combined with two doses of interleukin-2-receptor antagonist on day 0 and day 4. Intravenous methylprednisolone was given peri-operatively in a dose of $600 \mathrm{mg} / \mathrm{m}^{2}$. Prednisolone was started with $60 \mathrm{mg} / \mathrm{m}^{2}$ at day 0 and tapered to $5 \mathrm{mg} / \mathrm{m}^{2}$ daily within the first 3 months, to $10 \mathrm{mg} / \mathrm{m}^{2}$ every other day within the following 3 months and to $5 \mathrm{mg} / \mathrm{m}^{2}$ every other day from 6 months post-transplant onwards. The dose was not regularly modified or stopped upon EBV-infection or reactivation. Tacrolimus was initially given in a dose of $0.2 \mathrm{mg} / \mathrm{kg}$ daily and then adjusted to maintain trough levels of 5 to $8 \mathrm{ng} / \mathrm{ml}$ in 
Table 1 Patient characteristics

\begin{tabular}{|c|c|c|c|c|}
\hline \multirow[t]{2}{*}{ Characteristics } & \multirow{2}{*}{$\begin{array}{l}\text { All patients } \\
n=58(100 \%)\end{array}$} & \multicolumn{2}{|c|}{ EBV carrier state } & \multirow[t]{2}{*}{$p$ value } \\
\hline & & $\begin{array}{l}\text { CHL } \\
n=14 \\
(24 \%)\end{array}$ & $\begin{array}{l}\text { Non-CHL } \\
n=44 \\
(76 \%)\end{array}$ & \\
\hline Age at renal transplantation; median, (range) (year) & $10(1-17)$ & $2(1-15)$ & $12(2-17)$ & $<0.0001$ \\
\hline Boys/girls & $29 / 29$ & $10 / 4$ & $19 / 25$ & 0.12 \\
\hline \multicolumn{5}{|l|}{ Diagnosis: } \\
\hline CAKUT & 25 & $10(71 \%)$ & $15(34 \%)$ & \multirow[t]{4}{*}{0.021} \\
\hline Hereditary disorders & 18 & $3(22 \%)$ & $15(34 \%)$ & \\
\hline Acquired diseases & 13 & $1(7 \%)$ & $12(27 \%)$ & \\
\hline Unknown & 2 & - & $2(5 \%)$ & \\
\hline No dialysis prior to tx & 23 & $5(36 \%)$ & $18(41 \%)$ & \multirow[t]{3}{*}{0.98} \\
\hline HLA mismatch $0-2$ & 26 & $5(36 \%)$ & $21(48 \%)$ & \\
\hline $3-4$ & 23 & $8(57 \%)$ & $15(34 \%)$ & \\
\hline $5-6$ & 9 & $1(7 \%)$ & $8(18 \%)$ & 0.97 \\
\hline Living donor & 44 & $13(93 \%)$ & $31(70 \%)$ & 0.17 \\
\hline Cold ischemic time; median, (range) (h) & $2^{\mathrm{a}}(1-18)$ & $1.8^{\mathrm{a}}(1.3-9)$ & $2.1^{\mathrm{a}}(1-18)$ & 0.10 \\
\hline \multicolumn{5}{|l|}{ Initial immunosuppressive regimen: } \\
\hline Interleukin-2 receptor antagonist & 38 & 6 & 32 & \\
\hline Cyclosporine A & 2 & 0 & 2 & \\
\hline Tacrolimus & 56 & 14 & 42 & \\
\hline Mycophenolate mofetil & 58 & 14 & 44 & \\
\hline Corticosteroids & 58 & 14 & 44 & \\
\hline \multicolumn{5}{|l|}{ GFR; median (range) $\left(\mathrm{ml} / \mathrm{min} / 1.73 \mathrm{~m}^{2}\right)$} \\
\hline 3 months after $t x$ & $69(25-114)$ & $82(51-114)$ & $67(25-103)$ & 0.0016 \\
\hline 1 year after tx & $69^{\mathrm{b}}(39-109)$ & $76(53-109)$ & $67^{\mathrm{b}}(39-96)$ & \multirow[t]{2}{*}{0.19} \\
\hline Post-tx follow-up time; median, (range) (year) & $3.7(0.4-13)$ & $7.8(0.7-13)$ & $2.9(0.4-11)$ & \\
\hline Rejection & 16 & 3 & 13 & 0.83 \\
\hline Second renal transplantation & 1 & 1 & 0 & \\
\hline Ad mortem & 1 & 0 & 1 & \\
\hline
\end{tabular}

Values are expressed as number (\%), unless specified. For categorical variables, $n(\%)$ is presented. For continuous variables median (min; max)/ is presented. For comparison between groups, Fisher's exact test (lowest one-sided $p$ value multiplied by 2 ) was used for dichotomous variables and the Mantel-Haenszel chi-square test was used for ordered categorical variables and chi-square test was used for non-ordered categorical variables and the Mann-Whitney $U$ test was used for continuous variables.

CHL chronic high load, non-CHL non-chronic high load consisting of low viral load (LVL) and undetectable viral load (UVL), CAKUT congenital anomalies of the kidney and urinary tract, GFR glomerular filtration rate, $t x$ transplantation

${ }^{a}$ Cold ischemic time for four patients were lacking $(n=54)$, two patients in the CHL group $(n=12)$ and two in the non-CHL group ( $\left.n=42\right)$

${ }^{\mathrm{b}}$ GFR-data for one patient at 1 year post-transplant missing because deceased ( $n=57$ in all patients and $n=43$ in non-CHL)

whole blood for the first 3 months, and 4 to $7 \mathrm{ng} / \mathrm{ml}$ thereafter. Prior to 2010, the target levels for tacrolimus were higher in the first months post-transplant (10 to $12 \mathrm{ng} / \mathrm{ml})$.

Cyclosporine A trough levels in whole blood were maintained at 150 to $200 \mathrm{ng} / \mathrm{ml}$. MMF was given in a dose of 600 $\mathrm{mg} / \mathrm{m}^{2}$ daily. The dose was adjusted to meet mycophenolic acid area-under-the curve (MPA-AUC), with target levels of 40 to $60 \mathrm{mg}$ per liter and hour [28].

Immunosuppression was assessed at each clinical visit and individually adjusted. When EBV or CMV DNA was detected, the DNA levels were surveilled more frequently and reduction of immunosuppression was considered when EBV or CMV DNA levels of $\geqq 3 \log _{10} \mathrm{Geq} / \mathrm{ml}$ were reached. Thereafter, a stepwise reduction of MMF and tacrolimus was carried out if the EBV DNA levels increased $\geqq 0.5 \log _{10} \mathrm{Geq} /$ $\mathrm{ml}$ or levels above $4 \log _{10} \mathrm{Geq} / \mathrm{ml}$ were observed. When rejection was suspected, a renal biopsy was performed, and bolus doses of methylprednisolone were given when rejection was confirmed. Since 2013 onwards, the development of donor-specific antibodies (DSAs) was monitored. 


\section{Virological analyses}

All virological analyses were performed by accredited diagnostic assays at the Department of Clinical Microbiology, Sahlgrenska University Hospital. EBV IgG, IgM, and CMV IgM antibodies were analyzed using immunofluorescence, whereas CMV IgG antibodies were analyzed by an enzymelinked immunosorbent assay (ELISA). Both EBV IgG and IgM detect viral capsular antigens. Patients with an EBV or CMV IgM antibody titer of $\geqq 80$ indicated a primary infection. An EBV IgG antibody titer of $\geqq 32$ or a CMV IgG antibody titer of $\geqq 200$ was considered seropositive, indicating previous EBV or CMV antigen exposure. The patients and the donors were analyzed for EBV and CMV serology status pre-transplant, and determination of EBV and CMV antibodies in serum was performed 3 months post-transplant and then annually.

Serial measurements of EBV and CMV DNA load in blood samples were performed at least every week during the first 3 months, once monthly up to 1 year after transplantation and thereafter according to EBV and/or CMV PCR-status. When the levels of EBV or CMV DNA increased, when EBV or CMV infection was suspected, or when the patient was treated for rejection, samples were taken more often. EBV DNApositive patients were subsequently evaluated at regular intervals. Patients with rapidly rising levels or high levels for a long time were carefully examined for signs of PTLD. Clinical evaluations, laboratory tests, ultrasounds, or CTscans of suspected organs were performed and additional investigations such as biopsy of lymph nodes and specific organs were considered. The children were thereafter monitored weekly regarding clinical status, tacrolimus trough levels, serum levels of creatinine, and EBV DNA levels.

Serum and whole blood samples were analyzed for EBV and CMV DNA with a real-time quantitative PCR using primers and probes by Niesters et al. in 2002 [29]. The viral loads were calculated from the slope and intercept of the standard curve, and results were expressed as $\log _{10}$ genome equivalents (Geq) per $\mathrm{ml}$. The lower detection limit for the assays are $\approx 2.3 \log _{10}(\approx 200)$ Geq of EBV or CMV DNA per ml. The same assay has been used during the whole study period.

The criteria for EBV and CMV DNAemia, infections, and disease are presented in Table 2. EBV and CMV infection/ disease was defined as described by Bingler et al. [30] and Ljungman et al. [31].

\section{EBV DNA carrier states}

The children were divided into two groups according to their EBV DNA levels: chronic high EB viral load (CHL) and nonchronic high load (non-CHL). CHL was defined as the presence of EBV DNA $\geqq 4.2 \log _{10} \mathrm{Geq} / \mathrm{ml}$ in whole blood, in $>50$ $\%$ of the samples for $\geqq 6$ months as previously defined by
Green et al. [17]. Non-CHL consisted of patients with undetectable EB viral load (UVL) and patients with low EB viral load (LVL). UVL was defined as having no more than one sample of detectable EBV DNA levels following transplantation, and low EB viral load (LVL) included children not meeting criteria for UVL nor CHL.

\section{Antiviral prophylaxis and treatment}

All given blood products were leukocyte reduced. Antiviral prophylaxis with ganciclovir (before 2005) or valganciclovir (from 2005 onwards) was given to patients at high risk of primary CMV infection or at risk of CMV reactivation. Seronegative recipients received prophylaxis for 6 months in case of seropositive donor $(\mathrm{D}+/ \mathrm{R}-)$. Seropositive recipients $(\mathrm{R}+)$ received antiviral prophylaxis for 3 months. The prophylaxis was initiated about 7 days post transplantation. No prophylaxis was given to seronegative recipients with seronegative donors $\left(\mathrm{D}^{-} / \mathrm{R}^{-}\right)$except for four children who were considered to have an increased risk of contracting primary CMVinfection, such as having siblings in pre-school.

Antiviral treatment with ganciclovir or valganciclovir was given to patients with CMV DNA levels of $\geqq 3 \log _{10} \mathrm{Geq} / \mathrm{ml}$, quickly rising CMV DNA levels, primary CMV infection, or when symptomatic CMV infection was suspected.

\section{Statistical methods}

Age and calculated values for time after transplantation are expressed as median (range), unless specified. Categorical variables are described by number and percentage.

Mann-Whitney $U$ test was used for comparisons between CHL and non-CHL with respect to continuous variables in Fig. 2. Mantel-Haenszel Chi-square test was used to test between the two groups (CHL and non-CHL) with respect to ordered categorical variables (for example age categories) and chi-square for non-ordered categorical variables (for example different diagnoses analyzed with one variable).

The incidence of CHL was described by crude event rates per 100 person-years, computed as number of events divided by number of follow-up time per 100 years. The $95 \%$ CIs were calculated using exact Poisson confidence limits. The impact of age at transplantation, sex, diagnosis, HLA mismatch, living donor, no dialysis before transplantation, and cold ischemic time on time to CHL were evaluated by univariable Cox proportional hazards models. Time-updated Cox regression was applied when studying the impact of primary infection/re-activation among all patients and primary infection among seronegative patients at transplantation. Hazard ratios (HRs) with 95\% confidence intervals (CIs) are presented as effect sizes. The assumption of proportional hazards in the models was checked by investigating $\log (-\log$ (survival)) vs. $\log$ (time) curves and by introducing an 
Table 2 Definitions of EBV and CMV infections

\begin{tabular}{|c|c|}
\hline Categories & Definition/criteria \\
\hline EBV or CMV DNAemia/infection & Detection of EBV and/or CMV DNA by PCR in serum or whole blood at least twice within a month \\
\hline Primary EBV or CMV infection & $\begin{array}{l}\text { Detection of viral DNA in serum, whole blood, any body fluid, or tissue specimen by PCR in a previously } \\
\text { seronegative person }\end{array}$ \\
\hline Reactivated EBV or CMV infection & $\begin{array}{l}\text { Detection of EBV and/or CMV DNA in serum, whole blood, any body fluid or tissue specimen at least twice } \\
\text { within a month in a previously seropositive individual }\end{array}$ \\
\hline Asymptomatic infection & $\begin{array}{l}\text { Presence of EBV and/or CMV DNA in serum, whole blood, any body fluid, or tissue specimen in the } \\
\text { absence of symptoms or when symptoms were more likely due to other causes }\end{array}$ \\
\hline $\begin{array}{l}\text { Symptomatic EBV or CMV } \\
\text { infection/disease }\end{array}$ & $\begin{array}{l}\text { Presence of EBV and/or CMV DNA in serum, whole blood, any body fluid, or tissue specimen in combi- } \\
\text { nation with symptoms such as prolonged fever, malaise, night sweats, lymphadenopathy, pharyngitis, } \\
\text { tonsillitis, and/or hepatitis, without histological evidence of PTLD or CMV tissue invasive disease }\end{array}$ \\
\hline CMV tissue invasive disease & $\begin{array}{l}\text { Detection of CMV DNAemia and evidence of organ involvement (hepatitis, gastrointestinal disease etc.), } \\
\text { based on symptoms and/or pathology }\end{array}$ \\
\hline EBV and CMV co-infection & $\begin{array}{l}\text { Detection of CMV DNAemia in patients belonging to the EBV-groups LVL or CHL. CMV DNA should be } \\
\text { detected within } 1 \text { month before, after, or at the same time as EBV DNA was detected. }\end{array}$ \\
\hline
\end{tabular}

interaction term with log (time) in the model and was found satisfactory. The only independent significant predictor was age at transplantation; hence, no multivariable model was constructed.

All tests were two-tailed and conducted at a significance level of 0.05 . The analyses were performed using SAS software version 9.4 (SAS Institute Inc., Cary, NC, USA).

\section{Results}

\section{Patient characteristics}

The characteristics of the 58 renal transplant patients are presented in Table 1. The age at transplantation ranged from 1 to 17 years (median 10). Half of the children were boys and $40 \%$ were transplanted without prior dialysis. Congenital anomalies of the kidney and urinary tract (CAKUT) and hereditary disorders were the most common underlying diseases. Living related donors were used in 44 patients $(76 \%)$. The median donor age was 39 years $(0.3-57)$. The median follow-up time post-transplant was 3.7 years $(0.4-13)$ in the whole cohort. The cold ischemic time was $2 \mathrm{~h}$ (1-18). Fifteen patients (26\%) developed acute cellular graft rejection, and one patient developed an early acute antibody-mediated rejection. There was no difference between the patients in the CHL group compared to the non-CHL group in immunosuppressive treatment or rejections. The initial immunosuppressive protocol and follow-up was the same in all children but was individualized during follow-up depending on EBV status. Median GFR 3 months post-transplant was 69 (25-114) and after 1 year $69 \mathrm{ml} / \mathrm{min} / 1.73 \mathrm{~m}^{2}$ (39-109). Patients in the non-CHL group had a shorter follow-up time than patients in the CHL group. Thirty-one patients were censored when reaching 18 years of age, one patient at the time of re-transplantation 7.3 years post-transplant and the others at the end of follow-up. One patient died 9 months after transplantation due to bacterial pneumonia and multi-organ failure while having high EBV DNA levels (maximum level at $4.07 \log _{10} \mathrm{Geq} / \mathrm{ml}$, but not qualifying for $\mathrm{CHL}$ ) and concomitant CMV DNAemia, which was treated with ganciclovir.

\section{EBV status}

Thirty-one $(53 \%)$ of the recipients were EBV seronegative before transplantation (Fig. 1; Table 3). Twenty-eight (90\%) of them received an organ from an EBV-seropositive donor (D+/R-). Serostatus for the remaining three donors was unknown. Post-transplant, $25(81 \%)$ of the seronegative recipients developed a primary EBV infection after a median of 43 days (14-363), while six patients remained EBV sero- and DNA-negative during follow up (Figs. 1 and 2).

Twenty-seven patients were EBV seropositive at transplantation, and in $20(74 \%)$ of them, EBV reactivated after 12 days (0-64). EBV DNA in whole blood became negative in 13 of these patients after 3.2 years $(0.1-8)$, while seven patients remained EBV DNA positive at last follow up. The seven patients who did not reactivate EBV post-transplant had a median age at transplantation of 14 years (7-17), for details see Fig. 2.

The initial immunosuppressive protocol was the same in all 58 patients. Among the 44 patients in the non-CHL-group, 13 experienced sporadic high EBV DNA loads: eight developed primary EBV infection and five a reactivated infection. These 13 were assumed to be at risk for developing CHL and PTLD, and therefore, the immunosuppression was reduced in the same way as for CHL carriers. 
Fig. 1 EBV outcome. Enrollment and follow up showing the pretransplant EBV serostatus of renal transplant recipients and the development of EBV DNA positivity, i.e., chronic high load (CHL) and low viral load (LVL) and EBV DNA negativity, i.e., undetected viral load (UVL) during follow up. Tx transplantation

Table 3 EBV and CMV characteristics of donors and recipients of renal transplants

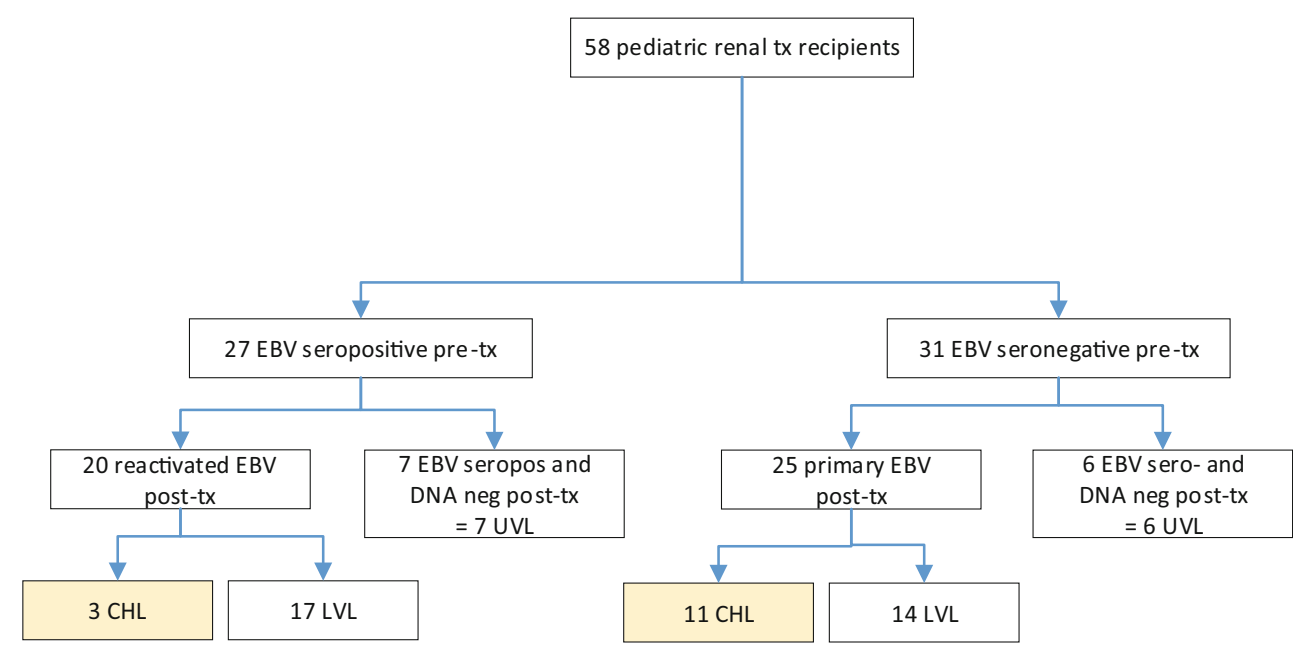

\begin{tabular}{|c|c|c|c|}
\hline \multirow[t]{3}{*}{ Characteristics } & \multirow{3}{*}{$\begin{array}{l}\text { All patients } \\
n=58(100 \%)\end{array}$} & \multicolumn{2}{|c|}{ EBV carrier state } \\
\hline & & $\mathrm{CHL}$ & Non-CHL \\
\hline & & $n=14(24 \%)$ & $n=44(76 \%)$ \\
\hline \multicolumn{4}{|l|}{ EBV serostatus } \\
\hline $\mathrm{D}^{+} / \mathrm{R}^{-}$ & 28 & $10(71 \%)$ & $18(41 \%)$ \\
\hline $\mathrm{D}^{+} / \mathrm{R}^{+}$ & 18 & $3(21 \%)$ & $15(34 \%)$ \\
\hline $\mathrm{D}^{?} / \mathrm{R}^{+}$ & 9 & 0 & $9(20 \%)$ \\
\hline $\mathrm{D}^{?} / \mathrm{R}^{-}$ & 3 & $1(7 \%)$ & $2(5 \%)$ \\
\hline \multicolumn{4}{|l|}{ CMV serostatus } \\
\hline $\mathrm{D}^{+} / \mathrm{R}^{-}$ & 18 & $5(36 \%)$ & $13(30 \%)$ \\
\hline $\mathrm{D}^{+} / \mathrm{R}^{+}$ & 17 & $3(21 \%)$ & $14(32 \%)$ \\
\hline $\mathrm{D}^{-} / \mathrm{R}^{+}$ & 6 & 0 & $6(14 \%)$ \\
\hline $\mathrm{D}^{-} / \mathrm{R}^{-}$ & 17 & $6(43 \%)$ & $11(25 \%)$ \\
\hline EBV and CMV seropositive donor & 27 & $7(50 \%)$ & $20(45 \%)$ \\
\hline EBV and CMV seropositive recipient & 13 & 0 & $13(30 \%)$ \\
\hline EBV: DNAemia & 45 & $14(100 \%)$ & $31(70 \%)$ \\
\hline Primary infection & 25 & 11 & 14 \\
\hline Reactivated infection & 20 & 3 & 17 \\
\hline Symptomatic infection & 13 & 8 & 5 \\
\hline CMV: DNAemia & 25 & $8(57 \%)$ & $17(39 \%)$ \\
\hline Primary infection & 13 & 5 & 8 \\
\hline Reactivated infection & 12 & 3 & 9 \\
\hline Symptomatic infection & 10 & 6 & 4 \\
\hline Co-infection EBV and CMV & 19 & $8(18 \%)$ & $11(25 \%)$ \\
\hline \multicolumn{4}{|l|}{ CMV prophylaxis } \\
\hline None & 13 & 2 & 11 \\
\hline 3 months (CMV D-R+ or D+R+) & $24^{\mathrm{a}}$ & $5^{\mathrm{b}}$ & $19^{\mathrm{a}}$ \\
\hline 6 months (CMV D+R-) & $21^{\mathrm{a}}$ & $7^{\mathrm{a}, \mathrm{b}}$ & $14^{\mathrm{c}}$ \\
\hline Antiviral treatment of CMV & 3 & - & 3 \\
\hline
\end{tabular}

CHL chronic high load, non-CHL non-chronic high load consisting of low viral load and undetectable viral load, $D$ donor serostatus, $R$ recipient serostatus

${ }^{\text {a }}$ Ganciclovir as CMV prophylaxis post-transplant was given to two patients in the CHL group for 6 months (CHL 13 and 14 in Table 4) and to one patient in the LVL group for 3 months. All the other patients received valganciclovir

${ }^{\mathrm{b}}$ Valganciclovir as CMV prophylaxis was given to four patients in the CHL group even though $\mathrm{D}-/ \mathrm{R}-$, two for 3 months and two for 6 months because of increased risk of contracting primary CMV infection such as having siblings in pre-school

${ }^{\mathrm{c}}$ Valganciclovir as CMV prophylaxis was given for 6 months to three patients in the non-CHL group even though $\mathrm{D}+\mathrm{R}+$ because of increased risk of contracting primary CMV infection such as receiving anti-rejection treatment 
Fig. 2 Distribution of age at transplantation for kidney recipients with different EBV status at transplantation/follow up, divided by those who developed chronic high EBV load (CHL) and non-CHL. Younger age and more EBV naive children at transplantation (tx) are seen in the CHL group in red compared to the non-CHL group in blue. Fourteen non-CHL and $11 \mathrm{CHL}$ patients had a primary EBV infection. Seventeen non-CHL and three CHL patients had a reactivated $\mathrm{EBV}$ infection. Seven non-CHL patients that were EBV seropositive at transplantation stayed negative in EBV DNA measured by PCR method posttransplant

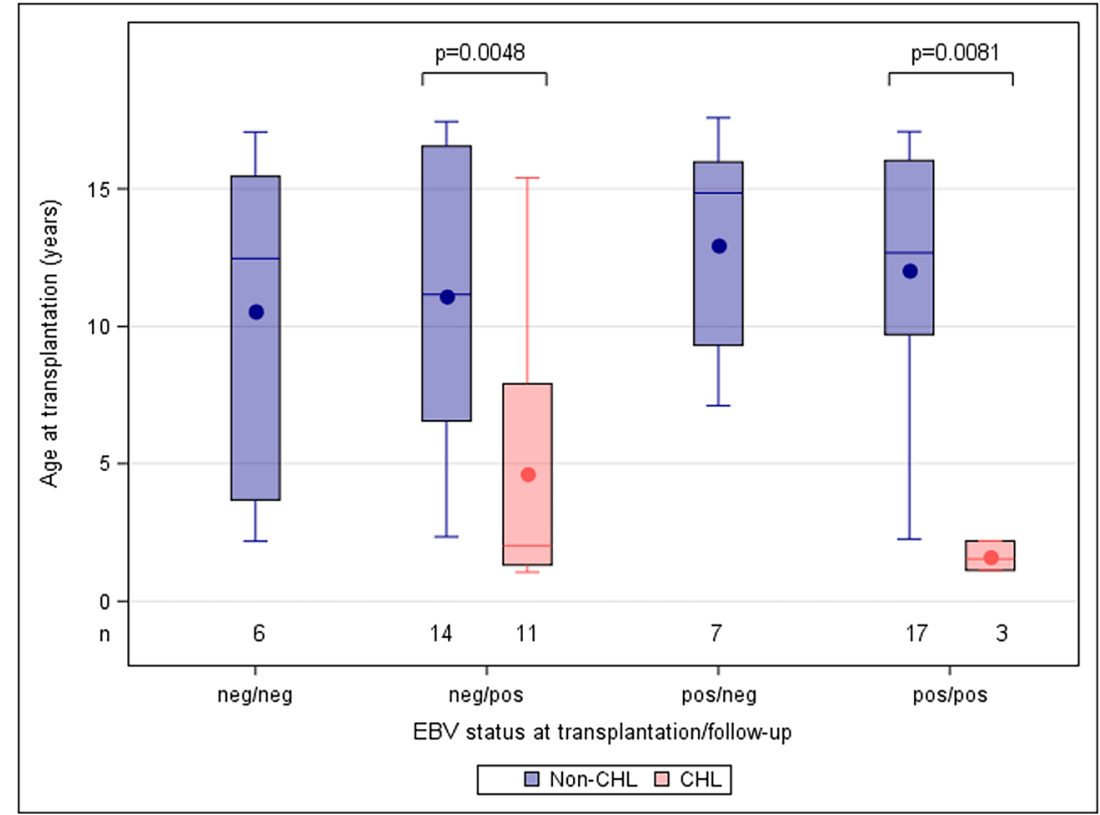

\section{EBV chronic high load (CHL)}

Altogether, 14 children developed CHL, starting at a median of 69 days (0-278) post-transplant (Table 4). Eleven (79\%) of the patients were EBV seronegative prior to transplantation and developed a primary EBV infection 40 days (26-82) post-transplant. Six patients developed CHL at the time when the primary EBV infection started, whereas five of the 11 patients developed CHL several months after the first positive EBV DNA. The remaining three patients developed CHL after a reactivation of EBV. All patients in the CHL group had their immunosuppression reduced because of high EBV loads. Target levels for tacrolimus were lowered to $<5 \mathrm{ng} / \mathrm{ml}$ followed by reduction of MMF, and because of persistent high EBV levels, MMF was withdrawn in five patients in this group. The maximum peak of EB viral load was $5.4(4.7-6.1) \log _{10} \mathrm{Geq} / \mathrm{ml}$ for the whole CHL group. The duration of CHL carriage varied between 0.5 and 6.5 years (median 2.0). Twelve children were CHL carriers for more than 1 year despite minimal immunosuppression. Three patients in the CHL group were treated for mild to moderate (one mild and two moderate) rejections with resolution of rejection. CHL-carriage was ongoing in two patients at the end of the study who had then experienced the CHL state for 7 and 78 months respectively. An example of prolonged high EBV DNA load despite low tacrolimus concentration (case CHL 6 in Table 4) is shown in Fig. 3.

Children with CHL had a follow-up time of 7.4 years (0.612) after high EBV load was first found. They were younger at transplantation (HR 0.74 [95\% CI 0.63 to 0.87], $p=0.0002$ ) and had a higher rate of congenital anomalies of the kidney and urinary tract (CAKUT) as underlying renal diagnosis (HR 3.92 [95\% CI 1.23 to 12.51 ], $p=0.021$ ) compared to the children who did not develop CHL (Table 5). When adjusting for age, the difference between CHL and non-CHL group was not significant regarding CAKUT $(p=0.16)$.

The clinical presentation of EBV infection among the $\mathrm{CHL}$ carriers was in most cases unspecific or asymptomatic (Table 4). Eight patients presented symptoms or clinical findings that could be caused by EBV, while EBV DNAemia was detected without any associated symptoms of active infection in six individuals.

Twelve of the 14 patients in the CHL group received CMVprophylaxis, including four $\mathrm{CMV} \mathrm{D}-\mathrm{R}-$ who were considered to have an increased risk of contracting primary CMVinfection (such as having siblings in pre-school).

The median GFR 3 months post-transplant was 82 (51$114)$ in the CHL group and $67 \mathrm{ml} / \mathrm{min} / 1.73 \mathrm{~m}^{2}(25-103)$ in the non-CHL group $(p=0.0016)$. One year after transplantation, GFR did not differ between the groups (Table 1).

Three patients in the CHL group (CHL 2, 3, and 6 in Table 4) with rapidly rising EBV DNA levels or high levels for a long time were carefully examined for signs of PTLD, as described in the "Methods." No patient developed PTLD, and no patient was treated with rituximab during a median clinical follow-up of 7.8 years $(0.7-13)$.

\section{CMV co-infections}

Among our 58 patients, 35 (60\%) were CMV seronegative prior to transplantation (Table 3 ). Of the 14 recipients who became EBV CHL carriers, five (36\%) had primary CMV infection and three (21\%) had reactivated CMV DNAemia, as compared to $8(18 \%)$ and $9(20 \%)$ children respectively, in the non-CHL group (Table 3 ).

Primary CMV before or at the same time as EBV DNAemia $(+/-1$ month) was seen in three patients ( $2 \mathrm{CHL}$ and 1 non-CHL) 





Fig. 3 Prolonged EBV DNA CHL carrier state in one patient despite low level of immunosuppression. The characteristics of the patient (CHL6) are described in Table 4. He received a kidney from a deceased donor. Both donor and recipient were EBV seropositive before transplantation $(\mathrm{D}+\mathrm{R}+)$. Immunosuppression was reduced to minimal dose of tacrolimus and steroids every other day. Mycophenolate mofetil was withdrawn 258 days after transplantation

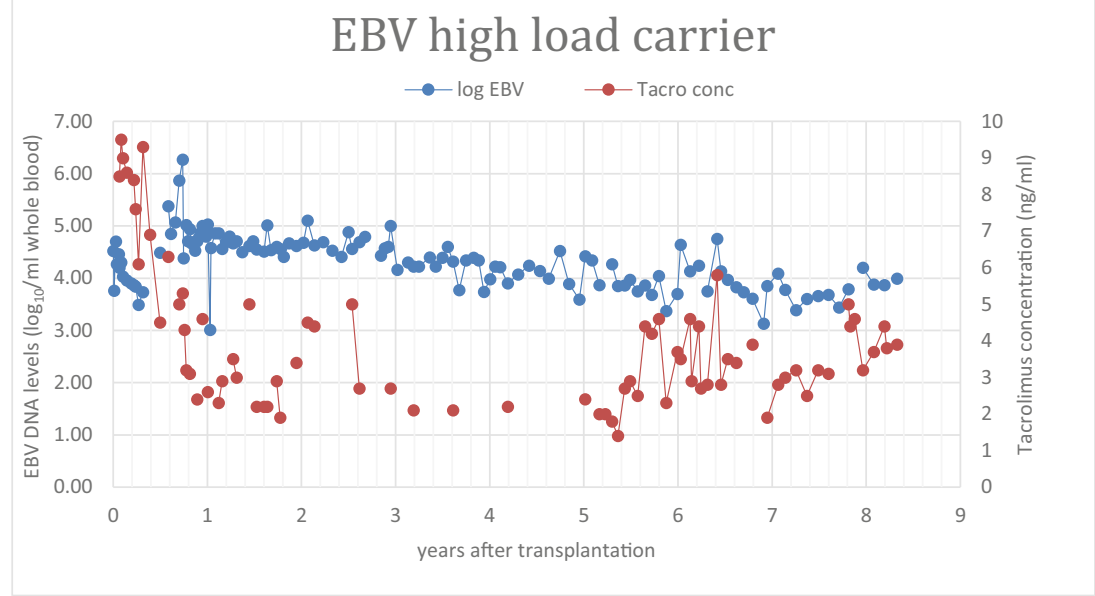

in the cohort. One of these patients had a primary CMV infection at the same time as the EBV high load period started (Table 3).

Symptoms that could be caused by CMV infection/disease developed in six CHL and four non-CHL patients. Of these, only three patients received antiviral treatment against CMV infection, two had primary infections and one reactivated, all belonging to the non-CHL group. One of these patients had leucopenia, diarrhea, and proctitis, and therefore, CMV tissue invasive disease was highly suspected. In addition, three patients had both EBV- and CMV-related symptoms. These patients presented only mild forms of infection, except for the third patient who died 9 months after transplantation due to bacterial pneumonia and multi-organ failure while having high EBV DNA levels in blood and concomitant CMV DNAemia.

\section{Discussion}

Our main findings were that as many as $24 \%$ of the children with kidney transplants developed a EBV chronic high load carrier state $(\mathrm{CHL})$, that many were $\mathrm{CHL}$ carriers for long periods of time despite reduced immunosuppression, and that no patient developed PTLD during follow up. Based on these findings, we suggest that an early detection of EBV DNAemia

Table 5 Univariate analysis of risk for CHL in cohort of our renal transplant recipients

\begin{tabular}{|c|c|c|c|c|}
\hline Variable & Category & $n(\%)$ & HR $(95 \%$ CI $)$ & $P$ value \\
\hline \multirow[t]{2}{*}{ Age at transplantation (years) } & $\leq 10$ & $13(44.8)$ & & \\
\hline & $>10$ & $1(3.4)$ & $0.74(0.63: 0.87)$ & 0.0002 \\
\hline \multirow[t]{2}{*}{ Sex } & Male & $10(34.5)$ & & \\
\hline & Female & $4(13.8)$ & $0.34(0.11: 1.10)$ & 0.072 \\
\hline \multirow[t]{2}{*}{ CAKUT } & No & $4(12.1)$ & & \\
\hline & Yes & $10(40.0)$ & $3.92(1.23: 12.51)$ & 0.021 \\
\hline \multirow[t]{3}{*}{ HLA mismatch } & $0-2$ & $5(19.2)$ & & \\
\hline & $3-4$ (vs $0-2$ ) & $8(34.8)$ & $1.89(0.62: 5.79)$ & ns \\
\hline & $5-6$ (vs $0-2)$ & $1(11.1)$ & $0.56(0.07: 4.82)$ & ns \\
\hline \multirow[t]{2}{*}{ Living donor } & No & $1(7.1)$ & & \\
\hline & Yes & $13(29.5)$ & $4.61(0.60: 35.30)$ & ns \\
\hline \multirow[t]{2}{*}{ dialysis before $\mathrm{tx}$} & No & $5(21.7)$ & & \\
\hline & Yes & $9(25.7)$ & $1.28(0.43: 3.81)$ & ns \\
\hline \multirow[t]{3}{*}{ Diagnosis } & CAKUT & $10(40.0)$ & & \\
\hline & Hereditary disorders vs CAKUT & $3(16.7)$ & $0.35(0.10: 1.28)$ & ns \\
\hline & Acquired diseases vs CAKUT & $1(7.7)$ & $0.16(0.02: 1.27)$ & 0.084 \\
\hline \multirow[t]{2}{*}{ EBV mismatch (D+R-) } & No & $3(15.0)$ & & \\
\hline & Yes & $10(35.7)$ & $2.56(0.70: 9.32)$ & ns \\
\hline \multirow[t]{2}{*}{ EBV serology in recipients } & Positive & $3(11.1)$ & & \\
\hline & Negative & $11(35.5)$ & $3.55(0.99: 12.76)$ & 0.052 \\
\hline
\end{tabular}

CAKUT congenital anomalies of the kidney and urinary tract, $C H L$ chronic high load, $H L A$ human leucocyte antigen, $t x$ transplantation 
due to frequent EBV load measurements can improve the possibilities to adapt immunosuppressive treatment and therefore possibly reduce complications in a long-term follow-up of pediatric renal transplant patients.

In the present study, the frequency of CHL carriers was higher than the $8 \%$ recently described by Yamada et al. [27], which to some extent might be due to the relatively small study group, but also to our more frequent EBV DNA measurements undertaken during the first years post-transplant. The median time to onset of CHL in our cohort was 69 days post-transplant which is shorter than the 104 days in a previous study [32]. The median CHL duration of 2 years is similar to the results of other studies, but the follow-up time of almost 8 years is longer than other comparable studies $[18,27,33]$. In a previous multicenter study, $2 \%$ of PTLD was reported following renal transplantation [34]. In our study of 58 children, there were no cases of PTLD, which also might be due to the limited study size. Our strength is that this is a single-center study where all patients were followed according to the same protocol, with frequent clinical check-ups by the same team of doctors and nurses and with close contact with the local hospital. In addition, all laboratory samples were analyzed with the same methods and with the same EBV DNA cut-offs.

Young age is a well-known risk factor for developing chronic high EBV load and PTLD [14, 34]. In our study, CHL was more frequent in young individuals and the children in the CHL-group were younger (median age 2 years) than described by Yamada et al. (median age 3.8 years) [27]. However, young age often coincides with being EBV seronegative which also predisposes for primary EBV infection and thereby also for CHL carriership and eventually PTLD. In our study, $53 \%$ of the patients were EBV seronegative before transplantation, which is similar to previous reports $[27,35,36]$. Eighty percent of our seronegative patients developed a primary EBV infection during the study period, which is higher than previous observations [18,27]. As many as $74 \%$ of our EBV seropositive patients reactivated their EBV infection, which is a higher rate than observed by Colombini et al. [18] and Höcker et al. [37], and our higher EBV rates are likely explained by our lower EBV threshold for classification (200 copies/ml as compared with 3000 copies $/ \mathrm{ml}$ and 1000 copies $/ \mathrm{ml}$, respectively, in their studies).

Green et al. $[17,38]$ have described the chronic high EB viral load as occurring more often after primary EBV infection and seldom as reactivated infections. Accordingly, in our study, out of $28 \mathrm{EBV}$ mismatch (D+/R-) patients, 25 (89\%) developed a primary EBV infection within 2 months after transplantation and $11(44 \%)$ progressed to CHL. In our CHL group, 11 patients were seronegative at transplantation and had a primary EBV infection post-transplant. The remaining three children had their first positive test for EBV at or shortly before transplantation. They were classified as EBV reactivation according to protocol. Since they had an active primary infection with early EBV IgG production at the time of transplantation and the introduction of immunosuppression, they may have performed more similarly to the children with primary infection post-transplant. This may explain the lack of difference in time interval to first occurrence of EBV DNAemia, maximum EBV level, or duration of CHL between the patients with primary and those with reactivated EBV infections. Thus, most children who developed CHL experienced a primary EBV-infection post transplantation, but this was not a statistically significant independent risk factor in our study when adjusting for age.

The increasing number of young renal transplant recipients may account for a higher rate of EBV-seronegative individuals receiving transplants, and thus also for primary EBV infection after transplantation. The risk of primary EBV infection after pediatric renal transplantation might lead to an increased prevalence of EBV-associated PTLD that could become a rising problem in the future [39].

In our group of 14 patients with CHL, we noted a higher rate of CAKUT ( $p=0.021)$ as pre-transplant renal diagnosis, which can be explained by young age at transplantation in patients with these diagnoses. When adjusting for age, there was no significant difference of CAKUT between the CHL and non-CHL groups. CAKUT are more common in boys and, although not significant, there was a trend of more boys in the CHL group.

Immunosuppression is another risk factor for developing CHL- and EBV-associated PTLD [16, 22, 25, 37]. Thus, the incidence of PTLD is higher in pediatric recipients of heart, lung, and intestinal transplants, traditionally treated with more intense immunosuppression, and lower in pediatric liver and renal recipients, who are treated with less intense immunosuppression $[6,17,40]$. In the present study, all children followed the same initial immunosuppressive protocol. Twenty-seven children (14 CHL and 13 non-CHL) had their immunosuppression reduced or MMF withdrawn because of increasing or maintaining high EBV DNA levels. Since the CHL children in our study were younger than the non-CHL children, their relatively immature immune systems without fully developed T-cell-response could have played a role. Thus, younger children might be over-immunosuppressed, which could have contributed to the development of CHL. Immunosuppression was increased in some specific situations, such as multiple HLAmismatches between donor and recipient or after acute cellular rejection, implying an increased risk for CHL and PTLD. On the other hand, there was a fear that the reduced immunosuppression in the CHL group would increase the incidence of rejections. Since no such increase of rejections was observed, the EBV CHL carriage and PTLD may be a manifestation of over-immunosuppression [16, 17, 25, 37].

There is no universally accepted approach for the management of post-transplant EBV infections. Reduction of the total burden of immunosuppression is one therapeutic option. In the 
present study, immunosuppression was reduced in all 14 patients in the CHL group and in several of the non-CHL patients due to short-term high EBV loads. The use of antiviral agents to prevent $\mathrm{EBV}$ infection in pediatric patients with EBV seroconversion is another, but controversial, option [6, 38, 41]. No additional antiviral therapy was applied in our patients.

Eight of the $14 \mathrm{CHL}$ patients were also co-infected with CMV. A similar frequency was seen in the non-CHL group. Primary CMV infections were seen in 36\% in the CHL-group compared to $18 \%$ in the non-CHL group. This is consistent with the results of previous investigations where primary CMV infection is described as a risk factor for CHL and PTLD [7, 23, 42]. In our study, we observed that CMV DNAemia arose in $64 \%$ of the children after antiviral prophylaxis was ceased. Antiviral prophylaxis has been shown to reduce the burden of CMV while postponing its occurrence until after prophylaxis cessation [43, 44]. Hence, our data supports the importance of assessing CMV DNA also after antiviral prophylaxis has been ceased.

EBV viremia may be asymptomatic or related to nonspecific symptoms of infection. Of the 58 studied patients, 18 (31\%) developed symptoms during follow up that could have been caused by EBV or CMV infection. The clinical presentation of the patients with EBV infection ranged from vague gastrointestinal complaints to fulminant multi-organ failure. Eight (57\%) of the CHL patients had symptoms or clinical findings that could be attributed to EBV, as described in the "Results" and specified in Table 4. As in previous studies, the difficulty of attributing symptoms to EBV, CMV, or other viral and bacterial infections is a limitation. For example, it could not be established to what extent EBV or CMV contributed to death 9 months post-transplant in one of our patients.

High EBV DNA levels have been recognized as a risk factor for developing PTLD in transplant recipients [2, 22, 45]. However, children may remain in a CHL carrier state without developing PTLD, and high or persistent EBV load alone does not appear to be predictive for development of PTLD in pediatric renal transplant recipients $[25,46]$. On the other hand, EBVassociated PTLD has been reported to occur in $1-7 \%$ of pediatric renal transplant recipients $[13,15]$. Despite the association between EBV infection and PTLD, there is still no consensus on viral load monitoring or the benefits of EBV antiviral prophylaxis/treatment. Better understanding of the relationship between EBV viral load and the risk of developing PTLD after renal transplantation is required [2, 25]. Risk factors of potential importance are the intensity of immunosuppressive therapy $[30,37]$, the EBV virulence [47], the nature of EBV-infected B-cells [48], the EBVspecific T-cell response [49], and a genetic predisposition [50].

A previous study did observe an association between subclinical EBV infection and impaired graft function in pediatric renal transplant patients [51]. In our study, as well as in another previous study by Höcker et al. [37], no significant difference in GFR decline was found between patients with or without EBV infection. In our study, the GFR 3 months after transplantation was higher in the CHL-group compared to the non-CHL-group, probably because of the patients' lower age. However, to detect any significant impact of EBV-infection on graft survival, a larger prospective study is needed.

The present study suggests that close monitoring of EBV DNA levels post-transplant can facilitate the identification of patients at risk of developing CHL and PTLD. Because early primary EBV infection is a risk for chronic EBV-associated diseases, avoiding primary infection post-transplant would be important, but is difficult since most organ donors are EBV seropositive, and because exposure to EBV is frequent at an early age.

\section{Conclusion}

CHL carriage after renal transplantation occurred frequently (24\%), was often long lasting, and developed mainly in younger children. The absence of PTLD in our patients suggests that monitoring of EBV DNA to guide immunosuppression may be effective in reducing the risk of PTLD. Future studies should aim at identifying additional risk factors for PTLD to modify the intensity and duration of monitoring. The increasing number of renal transplantations at younger age will probably lead to higher rates of primary EBV-infection and CHL in recipients in the future. Understanding the risk of EBV load in different organ transplant settings will aid clinical decisions regarding immunosuppression levels when balancing the risk of rejection and infection.

Acknowledgments The authors thank Henrik Albrektsson and Aldina Pivodic at Statistiska Konsultgruppen for expert assistance with the statistical analyses.

Financial support This work was supported financially by the Gothenburg Medical Society, Frimurare Barnhusdirektionen in Gothenburg, Märta and Gustaf Ågrens Stiftelse and grants from the Swedish state under the agreement between the Swedish government and the country councils, the ALF-agreement (ALF GBG 74040, 71550, 70450, 70150, and 73740).

Funding information Open access funding provided by University of Gothenburg.

\section{Compliance with ethical standards}

Ethical approval The investigation was approved by the Ethics Committee for Medical Research at Gothenburg University (No. 54913). All procedures performed in studies involving human participants were in accordance with the ethical standards of the institutional and/or national research committee and with the Helsinki declaration and its later amendments or comparable ethical standards.

Open Access This article is distributed under the terms of the Creative Commons Attribution 4.0 International License (http:// creativecommons.org/licenses/by/4.0/), which permits unrestricted use, distribution, and reproduction in any medium, provided you give appropriate credit to the original author(s) and the source, provide a link to the Creative Commons license, and indicate if changes were made. 


\section{References}

1. Campe H, Jaeger G, Abou-Ajram C, Nitschko H, Griebel M, Montoya C, Klare B, Koszinowski U (2003) Serial detection of Epstein-Barr virus DNA in sera and peripheral blood leukocyte samples of pediatric renal allograft recipients with persistent mononucleosis-like symptoms defines patients at risk to develop post-transplant lymphoproliferative disease. Pediatr Transplant 7:46-52

2. Suzuki T, Ikezumi Y, Okubo S, Uchiyama M, Takahashi K, Shiraga H, Hattori M (2007) Epstein-Barr virus DNA load and seroconversion in pediatric renal transplantation with tacrolimus immunosuppression. Pediatr Transplant 11:749-754. https://doi.org/10.1111/j. 1399-3046.2007.00738.x

3. Dharnidharka VR, Webster AC, Martinez OM, Preiksaitis JK, Leblond V, Choquet S (2016) Post-transplant lymphoproliferative disorders. Nat Rev Dis Primers 2:15088

4. Dierickx D, Habermann TM (2018) Post-transplantation lymphoproliferative disorders in adults. N Engl J Med 378:549-562

5. Knight JS, Tsodikov A, Cibrik DM, Ross CW, Kaminski MS, Blayney DW (2009) Lymphoma after solid organ transplantation: risk, response to therapy, and survival at a transplantation center. J Clin Oncol 27: 3354-3362. https://doi.org/10.1200/JCO.2008.20.0857

6. Dharnidharka VR, Araya CE (2009) Post-transplant lymphoproliferative disease. Pediatr Nephrol 24:731-736. https://doi.org/10. 1007/s00467-007-0582-3

7. Sampaio MS, Cho YW, Shah T, Bunnapradist S, Hutchinson IV (2012) Impact of Epstein-Barr virus donor and recipient serostatus on the incidence of post-transplant lymphoproliferative disorder in kidney transplant recipients. Nephrol Dial Transplant 27:29712979. https://doi.org/10.1093/ndt/gfr769

8. Allen UD, Preiksaitis JK, Practice ASTIDCo (2013) Epstein-Barr virus and posttransplant lymphoproliferative disorder in solid organ transplantation. Am J Transplant 13(Suppl 4):107-120. https://doi. org/10.1111/ajt.12104

9. Shapiro R, Nalesnik M, McCauley J, Fedorek S, Jordan ML, Scantlebury VP, Jain A, Vivas C, Ellis D, Lombardozzi-Lane S (1999) Posttransplant lymphoproliferative disorders in adult and pediatric renal transplant patients receiving tacrolimus-based immunosuppression. Transplantation 68:1851

10. Chen JM, Barr ML, Chadburn A, Frizzera G, Schenkel FA, Sciacca RR, Reison DS, Addonizio LJ, Rose EA, Knowles DM (1993) Management of lymphoproliferative disorders after cardiac transplantation. Ann Thorac Surg 56:527-538

11. Reyes J, Green M, Bueno J, Jabbour N, Nalesnik M, Yunis E, Kocoshis S, Kauffman M, Todo S, Starzl T (1996) Epstein Barr virus associated posttransplant lymphoproliferative disease after intestinal transplantation. In: Transplantation proceedings, vol 5. NIH Public Access, p 2768

12. Boyle GJ, Michaels MG, Webber SA, Knisely A, Kurland G, Cipriani LA, Griffith BP, Fricker FJ (1997) Posttransplantation lymphoproliferative disorders in pediatric thoracic organ recipients. J Pediatr 131:309-313

13. Srivastava T, Zwick DL, Rothberg PG, Warady BA (1999) Posttransplant lymphoproliferative disorder in pediatric renal transplantation. Pediatr Nephrol 13:748-754

14. Dharnidharka VR, Sullivan EK, Stablein DM, Tejani AH, Harmon WE (2001) Risk factors for posttransplant lymphoproliferative disorder (PTLD) in pediatric kidney transplantation: a report of the north american pediatric renal transplant cooperative study (NAPRTCS) 1. Transplantation 71:1065-1068

15. Holmes RD, Sokol RJ (2002) Epstein-Barr virus and post-transplant lymphoproliferative disease. Pediatr Transplantation 6:456-464

16. McDonald R, Smith J, Ho M, Lindblad R, Ikle D, Grimm P, Wyatt R, Arar M, Liereman D, Bridges N (2008) Incidence of PTLD in pediatric renal transplant recipients receiving basiliximab, calcineurin inhibitor, sirolimus and steroids. Am J Transplant 8:984-989

17. Green M, Soltys K, Rowe DT, Webber SA, Mazareigos G (2009) Chronic high Epstein-Barr viral load carriage in pediatric liver transplant recipients. Pediatr Transplant 13:319-323. https://doi. org/10.1111/j.1399-3046.2008.00926.x

18. Colombini E, Guzzo I, Morolli F, Longo G, Russo C, Lombardi A, Merli P, Barzon L, Murer L, Piga S, Ciofi Degli Atti ML, Locatelli F, Dello Strologo L (2017) Viral load of EBV DNAemia is a predictor of EBV-related post-transplant lymphoproliferative disorders in pediatric renal transplant recipients. Pediatr Nephrol 32:14331442. https://doi.org/10.1007/s00467-017-3627-2

19. Dharnidharka V, Martz K, Stablein D, Benfield M (2011) Improved survival with recent post-transplant lymphoproliferative disorder (PTLD) in children with kidney transplants. Am J Transplant 11: 751-758

20. Allen U, Hebert D, Moore D, Dror Y, Wasfy S, Group-CPS (2001) Epstein-Barr virus-related post-transplant lymphoproliferative disease in solid organ transplant recipients, 1988-97: a Canadian multi-centre experience. Pediatr Transplant 5:198-203

21. Maksten EF, Vase MO, Kampmann J, d'Amore F, Moller MB, Strandhave C, Bendix K, Bistrup C, Thiesson HC, Sondergaard E, Hamilton-Dutoit S, Jespersen B (2016) Post-transplant lymphoproliferative disorder following kidney transplantation: a population-based cohort study. Transpl Int 29:483-493. https://doi.org/10.1111/tri.12744

22. Shroff R, Trompeter R, Cubitt D, Thaker U, Rees L (2002) Epstein-Barr virus monitoring in paediatric renal transplant recipients. Pediatr Nephrol 17:770-775. https://doi.org/10.1007/s00467-002-0931-1

23. Caillard S, Dharnidharka V, Agodoa L, Bohen E, Abbott K (2005) Posttransplant lymphoproliferative disorders after renal transplantation in the United States in era of modern immunosuppression. Transplantation 80:1233-1243. https://doi.org/10.1097/01.tp. 0000179639.98338.39

24. Allen UD, Farkas G, Hebert D, Weitzman S, Stephens D, Petric M, Tellier R, Ngan B, Fecteau A, West L, Wasfy S (2005) Risk factors for post-transplant lymphoproliferative disorder in pediatric patients: a case-control study. Pediatr Transplant 9:450-455. https:// doi.org/10.1111/j.1399-3046.2005.00318.x

25. Tanaka E, Sato T, Ishihara M, Tsutsumi Y, Hisano M, Chikamoto H, Akioka Y, Dohno S, Maeda A, Hattori M, Wakiguchi H, Fujieda M (2011) Asymptomatic high Epstein-Barr viral load carriage in pediatric renal transplant recipients. Pediatr Transplant 15:306-313. https://doi.org/10.1111/j.1399-3046.2010.01465.x

26. Holmes MV, Caplin B, Atkinson C, Smith C, Harber M, Sweny P, Haque T (2009) Prospective monitoring of Epstein-Barr virus DNA in adult renal transplant recipients during the early posttransplant period: role of mycophenolate mofetil. Transplantation 87:852856. https://doi.org/10.1097/TP.0b013e318199f983

27. Yamada M, Nguyen C, Fadakar P, Ganoza A, Humar A, Shapiro R, Michaels MG, Green M (2018) Epidemiology and outcome of chronic high Epstein-Barr viral load carriage in pediatric kidney transplant recipients. Pediatr Transplant 22:e13147. https://doi. org $/ 10.1111 /$ petr.13147

28. Zhao W, Fakhoury M, Deschenes G, Roussey G, Brochard K, Niaudet $\mathrm{P}$, Tsimaratos M, Andre JL, Cloarec S, Cochat P, Bensman A, Azougagh S, Jacqz-Aigrain E (2010) Population pharmacokinetics and pharmacogenetics of mycophenolic acid following administration of mycophenolate mofetil in de novo pediatric renal-transplant patients. J Clin Pharmacol 50:1280-1291. https://doi.org/10.1177/ 0091270009357429

29. Niesters HG, Van Esser J, Fries E, Wolthers KC, Cornelissen J, Osterhaus AD (2000) Development of a real-time quantitative assay for detection of Epstein-Barr virus. J Clin Microbiol 38:712-715

30. Bingler MA, Feingold B, Miller SA, Quivers E, Michaels MG, Green M, Wadowsky RM, Rowe DT, Webber SA (2008) Chronic high Epstein-Barr viral load state and risk for late-onset posttransplant 
lymphoproliferative disease/lymphoma in children. Am J Transplant 8: 442-445. https://doi.org/10.1111/j.1600-6143.2007.02080.x

31. Ljungman P, Griffiths P, Paya C (2002) Definitions of cytomegalovirus infection and disease in transplant recipients. Clin Infect Dis 34:1094-1097

32. Ishihara M, Tanaka E, Sato T, Chikamoto H, Hisano M, Akioka Y, Dohno S, Maeda A, Hattori M, Wakiguchi H (2011) Epstein-Barr virus load for early detection of lymphoproliferative disorder in pediatric renal transplant recipients. Clin Nephrol 76:40-48

33. Laurent A, Klich A, Roy P, Lina B, Kassai B, Bacchetta J, Cochat P (2018) Pediatric renal transplantation: a retrospective single-center study on epidemiology and morbidity due to EBV. Pediatr Transplant 22:e13151. https://doi.org/10.1111/petr.13151

34. Moudgil A, Martz K, Moore T, Harmon WE, Dharnidharka VR (2014) Significance of asymptomatic persistent Epstein-Barr viral load in pediatric renal transplant recipients: North American pediatric renal trials and collaborative studies report. The Open Urology \& Nephrology Journal 7:123-128

35. Walker RC, Marshall WF, Strickler JG, Wiesner RH, Velosa JA, Habermann TM, McGregor CG, Paya CV (1995) Pretransplantation assessment of the risk of lymphoproliferative disorder. Clin Infect Dis 20:1346-1353

36. Ellis D, Jaffe R, Green M, Janosky JJ, Lombardozzi-Lane S, Shapiro R, Scantlebury V, Vivas C, Jordan ML (1999) Epstein-Barr virus-related disorders in children undergoing renal transplantation with tacrolimusbased immunosuppression. Transplantation 68:997-1003

37. Höcker B, Fickenscher H, Delecluse HJ, Bohm S, Kusters U, Schnitzler P, Pohl M, John U, Kemper MJ, Fehrenbach H, Wigger M, Holder M, Schroder M, Billing H, Fichtner A, Feneberg R, Sander A, Kopf-Shakib S, Susal C, Tonshoff B (2013) Epidemiology and morbidity of Epstein-Barr virus infection in pediatric renal transplant recipients: a multicenter, prospective study. Clin Infect Dis 56:84-92. https://doi.org/10.1093/cid/cis823

38. Green M, Michaels MG (2013) Epstein-Barr virus infection and posttransplant lymphoproliferative disorder. Am J Transplant 13(Suppl 3):41-54. https://doi.org/10.1111/ajt.12004

39. Sato T, Fujieda M, Tanaka E, Miyamura M, Chikamoto H, Hisano M, Akioka Y, Ishiura Y, Dohno S, Maeda A, Hattori M, Wakiguchi $\mathrm{H}$ (2008) Monitoring of Epstein-Barr virus load and antibody in pediatric renal transplant patients. Pediatr Int 50:454 458. https:// doi.org/10.1111/j.1442-200X.2008.02579.x

40. Pickhardt PJ, Siegel MJ, Hayashi RJ, Kelly M (2000) Posttransplantation lymphoproliferative disorder in children: clinical, histopathologic, and imaging features. Radiology 217:16-25
41. Höcker B, Bohm S, Fickenscher H, Kusters U, Schnitzler P, Pohl M, John U, Kemper MJ, Fehrenbach H, Wigger M, Holder M, Schroder M, Feneberg R, Kopf-Shakib S, Tonshoff B (2012) (Val-)Ganciclovir prophylaxis reduces Epstein-Barr virus primary infection in pediatric renal transplantation. Transpl Int 25:723-731. https://doi.org/10.1111/j.1432-2277.2012.01485.x

42. Shroff R, Rees L (2004) The post-transplant lymphoproliferative disorder - a literature review. Pediatr Nephrol 19:369-377

43. Paya C, Humar A, Dominguez E, Washburn K, Blumberg E, Alexander B, Freeman R, Heaton N, Pescovitz MD, Group VSOTS (2004) Efficacy and safety of valganciclovir vs. oral ganciclovir for prevention of cytomegalovirus disease in solid organ transplant recipients. Am J Transplant 4:611-620

44. Murray B, Subramaniam S (2004) Late cytomegalovirus infection after oral ganciclovir prophylaxis in renal transplant recipients. Transpl Infect Dis 6:3-9

45. Green M, Webber SA (2002) EBV viral load monitoring: unanswered questions. Am J Transplant 2:894-895

46. Qu L, Green M, Webber S, Reyes J, Ellis D, Rowe D (2000) Epstein-Barr virus gene expression in the peripheral blood of transplant recipients with persistent circulating virus loads. J Infect Dis 182:1013-1021

47. Snow AL, Martinez OM (2007) Epstein-Barr virus: evasive maneuvers in the development of PTLD. Am J Transplant 7:271-277. https://doi.org/10.1111/j.1600-6143.2006.01650.x

48. Thorley-Lawson DA (2001) Epstein-Barr virus: exploiting the immune system. Nat Rev Immunol 1:75-82

49. Mautner J, Bornkamm GW (2012) The role of virus-specific CD4+ $\mathrm{T}$ cells in the control of Epstein-Barr virus infection. Eur J Cell Biol 91:31-35

50. Subklewe M, Marquis R, Choquet S, Leblond V, Garnier J-L, Hetzer R, Swinnen LJ, Oertel S, Papp-Vary M, Gonzalez-Barca E (2006) Association of human leukocyte antigen haplotypes with posttransplant lymphoproliferative disease after solid organ transplantation. Transplantation 82:1093-1100

51. Smith JM, Corey L, Bittner R, Finn LS, Healey PJ, Davis CL, McDonald RA (2010) Subclinical viremia increases risk for chronic allograft injury in pediatric renal transplantation. J Am Soc Nephrol 21:1579-1586. https://doi.org/10.1681/ASN.2009111188.y

Publisher's note Springer Nature remains neutral with regard to jurisdictional claims in published maps and institutional affiliations. 